\title{
Contribution of infauna and mussel-raft epifauna to demersal fish diets
}

\author{
E. López-Jamar ${ }^{1}$, J. Iglesias ${ }^{2}$ and J. J. Otero ${ }^{2}$ \\ 1 Instituto Español de Oceanografía. Apartado 130, La Coruna, Spain \\ 2 Instituto Español de Oceanografía, Orillamar 47, Vigo, Spain
}

\begin{abstract}
The contribution of infauna and mussel-raft epifauna to the diet of 3 dominant species in the demersal fish community of the Ría de Arosa, N. W. Spain - Lesueurigobius friesii (Gobiidae), Callionymus lyra (Callionymidae) and Trisopterus luscus (Gadidae) - was determined. Intense raft mussel culture in the Ría de Arosa supports a rich epifauna which constitutes the main food resource for the fishes studied. In contrast, infauna density is low and contributes only a small proportion to fish diets. Prey consumed was similar in the 3 fish species. Gut contents consisted mainly of the small crab Pisidia longicomis. This decapod is a dominant component of the raft epifauna, and electivity indices indicate that it is selected by the fishes. In the Ría de Pontevedra, which contains fewer mussel rafts, these fish fed on infauna. Thus, one effect of intense mussel aquaculture has been to change the food habits of these 3 fishes from predominantly infauna to raft epifauna diet.
\end{abstract}

\section{INTRODUCTION}

One of the results of the intense mussel raft culture (over 2000 rafts) in the Ría de Arosa (Korringa, 1967; Tenore and González, 1975) is the presence of dense epifauna living on the mussel ropes (Román and Pérez, 1982). This rich epifauna feeds on the great amount of faeces and pseudofaeces egested by mussels, and can be a major food resource for demersal fishes (Chesney and Iglesias, 1979), and crabs (González-Gurriarán, 1981). In contrast, the large amount of detritus sedimenting from the mussel rafts causes a high deposition rate of organic matter into the sediment, resulting in an impoverishment of the infaunal communities in the Arosa (López-Jamar, 1982). This is in contrast to a dense infaunal assemblage found in the Ría de Muros to the North, a ría with less than 200 rafts (see Tenore et al., 1982, for further comparisons).

The Ría de Arosa demersal fish community is characterized by a large number of resident species, living in the ría during the whole year (Chesney and Iglesias, 1979). This study investigates the diets of 3 dominant species that represent $33 \%$ of the total number and $47 \%$ of the total biomass. Lesueurigobius friesii (Gobiidae), typically cited as an off-shore and deepwater species, is usually uncommon in shallow waters (Wheeler, 1969), yet is the most abundant species in the Ría de Arosa (Iglesias, 1981). It is strongly territo- rial, especially during breeding and feeding (Gibson, 1969). Therefore, it must live on prey existing in a limited area. On the other hand, Trisopterus luscus (Gadidae) is a very active predator that presumably can utilize prey from a wider range of habitats. Callionymus lyra (Callionymidae) is more dependent on sediment than $T$. Iuscus, but does not display territorial habits. Therefore, its diet should be less specialized than that of the goby, and it should use infauna as well as epifauna that fall from the rafts.

This paper explores the contribution of mussel-raft epifauna and infauna to the diets of these 3 dominant species.

\section{MATERIAL AND METHODS}

Trawl and grab samples were taken every 3 mo during 1980 in 2 different zones of the Ría de Arosa: a raft area (R) and a middle area (M) (Fig. 1). A $4.8 \mathrm{~m}$ semiballoon trawl with $3.7 \mathrm{~cm}$ stretched mesh and with a bait seine size of $1 \mathrm{~cm}$ was used for fish sampling. The effective opening of this trawl is $4 \mathrm{~m}$ wide and $1 \mathrm{~m}$ high (Haedrich and Haedrich, 1974); 10 min trawl at a speed of 1 knot was assumed to cover a bottom area of $800 \mathrm{~m}^{2}$ (Iglesias, 1981). Three infaunal samples were collected with a $0.05 \mathrm{~m}^{2}$ Van Veen grab, sieved through a $1 \mathrm{~mm}$ mesh, and preserved. A total of 100 


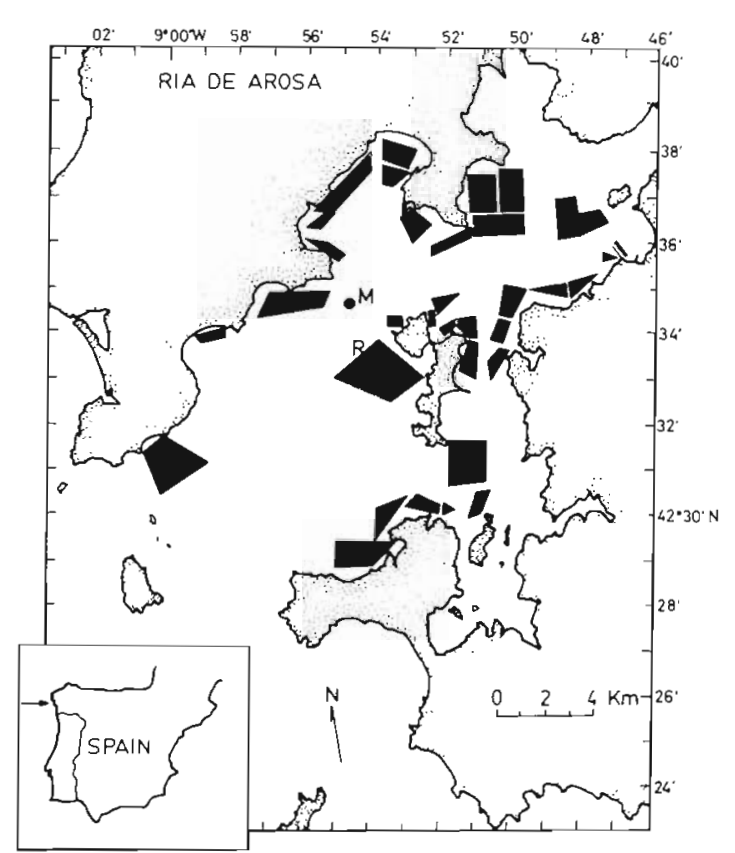

Fig. 1. Sampling sites in Ría de Arosa. M: middle station R: $^{2}$ raft station. Shaded areas correspond to groupings ('polygons') of mussel rafts

fishes of each species were examined seasonally, preserved in $4 \%$ formaldehyde for examination of stomach contents in the laboratory. Seasonal data on raft epifauna (species composition and abundance) of the studied area were available from a previous study (Román and Pérez, 1982).

The number of organisms, rather than biomass, was used to describe diets because of the uniformly small size of the prey species. Percentage composition of diet, infauna and raft epifauna was calculated in order to establish comparisons among samples. The composition of the diet was calculated for individual fish; then means for every area and season were estimated.

In order to test the food preferences of each species, the 'electivity index' of Ivlev (1961) was utilized. This index is subject to error in that it assumes equal 'availability' of prey to the fish and to the collecting gear, but has been used frequently in studies of trophic relations (Amtz, 1978; Jones, 1978). The formula is:

$$
E=(s-b) /(s+b)
$$

where $\mathrm{s}=\%$ in number of the food items in the stomach; $\mathrm{b}=\%$ in number of the food species in the field. Values of $E$ from 0 to 1 indicate prey selection, whereas values from 0 to -1 indicate prey rejection.

The Morisita index (Morisita, 1959) modified by Horn (1966) was used to indicate similarity between stomach contents and infaunal and epifaunal composition in the field:

$$
C_{\lambda}=\frac{2 \sum_{i=1}^{s} x_{i} y_{2}}{\left(\lambda_{x}+\lambda_{y}\right) X Y}\left(0 \leqslant C_{\lambda} \leqslant 1\right)
$$

where $s=$ total number of species in the two samples; $\mathrm{x}_{\mathrm{i}}=$ number of individuals of the ith species in the sample $x_{i} y_{L}=$ number of individuals of the $i$ th species in the sample $y ; X=$ total number of individuals in the sample $\mathrm{x} ; \mathrm{Y}=$ total number of individuals in the sample $y$

$$
\begin{aligned}
& \lambda_{\mathrm{x}}=\sum_{i=1}^{\mathrm{s}} \mathrm{x}_{\mathrm{i}}^{2} / \mathrm{X}^{2} \\
& \lambda_{\mathrm{Y}}=\sum_{\mathrm{i}=1}^{\mathrm{s}} \mathrm{Y}_{\mathrm{i}}^{2} / \mathrm{Y}^{2}
\end{aligned}
$$

The same index was used to estimate prey overlap among the 3 fish species.

\section{RESULTS}

\section{Seasonal and spatial variation of fish stomach con-} tents and infauna

As a first approach, we tested for seasonal differences of stomach contents and infauna samples by dividing the organisms into 5 main taxa: polychaetes, molluscs, echinoderms, crustaceans, and 'others' (nemerteans, nematodes, etc.). Excluding Callionymus lyra there were no major differences between raft and middle areas, nor among different seasons for fish stomach samples (Fig. 2). There did exist a great overall difference between the composition of grab samples versus stomach contents. In grab samples, polychaetes dominated, varying from 44 to $90 \%$ of total abundance, while crustaceans ranged from 0 to $36 \%$. In contrast, the crustaceans dominated fish stomach contents, especially for Trisopterus luscus, where values ranged from 84 to $100 \%$. Owing to the small spatial and temporal variations observed, we combined annual data on the following analysis.

\section{Comparison of fish diets with infauna and raft epifauna composition}

In the infauna samples, polychaetes constituted $77 \%$ of total abundance, whereas in raft epifauna and stomach samples they never exceeded $16 \%$ (Fig. 3). In contrast, crustaceans were not a very important part of the infauna $(7.4 \%)$, but were the dominant group both in raft epifauna $(74.2 \%)$ and in fish stomachs $(76.7$ to $98.5 \%$ ). Molluscs and echinoderms contributed only a very small proportion to total infauna, raft epifauna, and fish diet. Therefore, based on major groupings of 


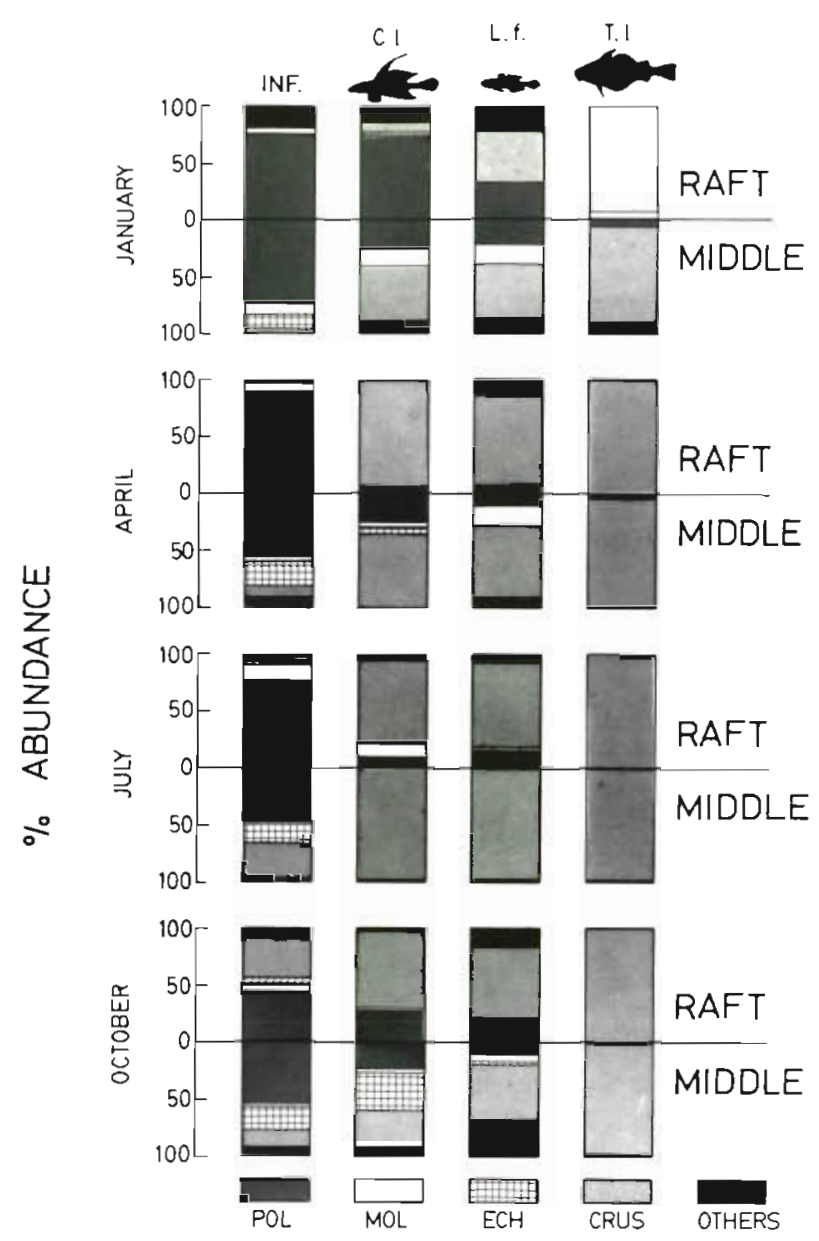

Fig. 2. Proportion of taxonomic groups in infaunal samples and in stomach contents of fishes from raft and middle stations in the different sampling periods. INF: infaunal samples; C. l.: Callionymus lyra; L. f.: Lesueurigobius friesii; T. 1.: Trisoptenus luscus; POL: polychaetes; MOL: molluscs; ECH: echinoderms; CRUS: crustaceans

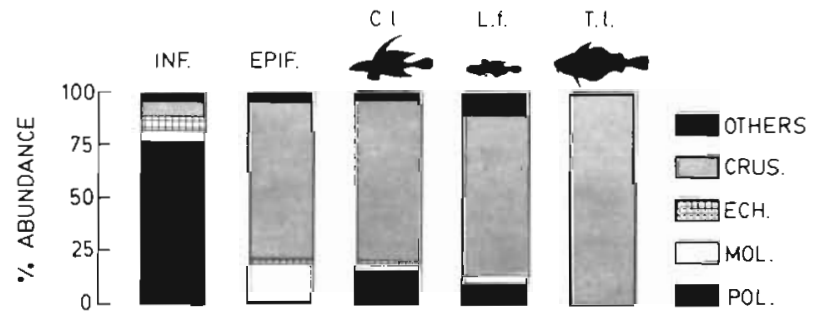

Fig. 3. Annual average proportion of taxonomic groups in infauna, epifauna and stomach contents of the 3 fishes studied (abbreviations as in Fig. 2)

taxa, the fish seem to feed mainly on raft epifauna rather than infauna.

Species composition of infauna, raft epifauna and stomach content of fishes is listed in Table 1. The similarity of fish diets with raft epifauna was relatively high, whereas similarity with infauna was much smal-
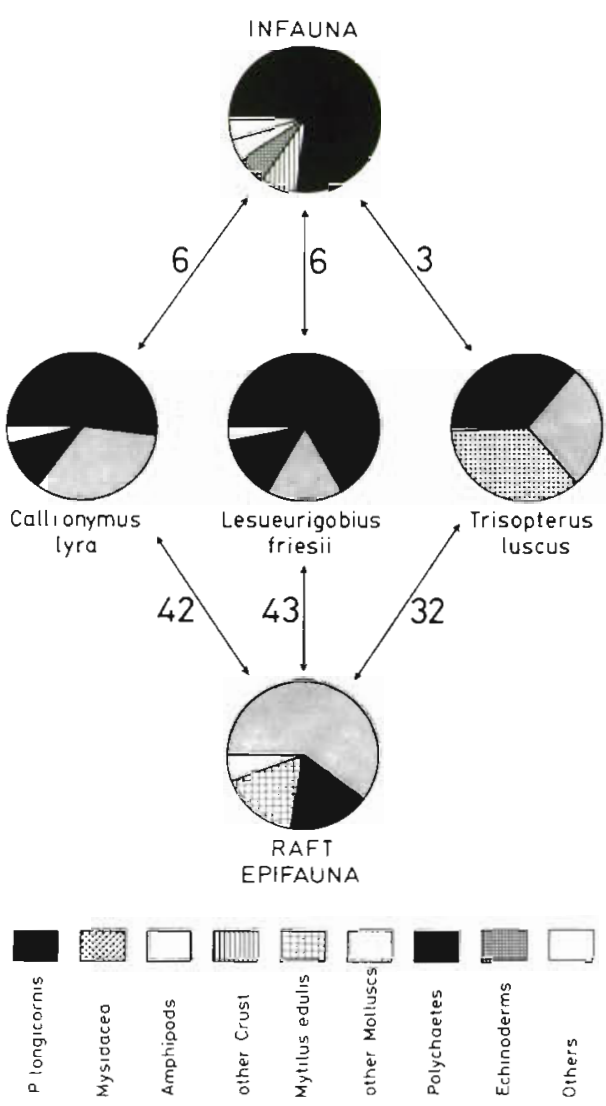

Fig. 4. Similarity of fish diets with infauna and raft epifauna. Numbers express percentage similarity

ler (Fig. 4). The gut contents of Callionymus lyra had $42 \%$ similarity with raft epifauna, mainly due to the dominance of the crab Pisidia longicornis. However, the similarity of $C$. lyra with infauna was very low $(6 \%)$.

Gut contents of Lesueurigobius friesii also showed a high similarity with raft epifauna (43\%), again because of a similar dominant, Pisidia longicornis. Similarity with infauna was only $6 \%$.

Similarity of stomach contents of Trisopterus luscus with raft epifauna was not as high (32\%) as in the former species. Pisidia longicornis was the main food item for this species, but an unidentified mysid, which does not occur in the raft epifauna, was also an important component of the diet. T. luscus consumed almost exclusively crustaceans (Fig. 2 and 3), and the similarity of its diet with infauna $(3 \%)$ is lower than in Callionymus lyra and Lesueurigobius friesii.

\section{Food selection and interspecific prey overlap}

As stated before, the diets of the fishes studied were closely related to the raft epifauna. The electivity indices and the proportion of each food item in the raft 
Table 1. Percentage composition of infaunal samples, epifaunal samples and stomach contents of fishes. Numbers in brackets: percentage of empty guts. (Data on raft epifauna after Román and Pérez, 1982)

\begin{tabular}{|c|c|c|c|c|c|c|c|c|c|c|c|}
\hline & $\begin{array}{l}{\left[x_{-}^{-}\right.} \\
\text {fauna }\end{array}$ & $\begin{array}{c}\text { Epi- } \\
\text { fauna }\end{array}$ & $\begin{array}{c}L . \\
\text { friesij }\end{array}$ & $\begin{array}{c}C . \\
\text { lyTa }\end{array}$ & $\begin{array}{c}T . \\
\text { luscus }\end{array}$ & & $\begin{array}{l}\text { In- } \\
\text { fauna }\end{array}$ & $\begin{array}{l}\text { Epi- } \\
\text { fauna }\end{array}$ & $\begin{array}{c}L . \\
\text { friesij }\end{array}$ & $\begin{array}{c}\text { C. } \\
\text { lyra }\end{array}$ & $\begin{array}{c}T \\
\text { luscus }\end{array}$ \\
\hline Polychaetes & & & $(11.5)$ & $(13.8)$ & $(8.6)$ & Thyasira flexuosa & 1.53 & & & & \\
\hline Prionospiosp. & 6.25 & & & 0.03 & & Hiatella arctica & & 0.13 & & & \\
\hline Tharyx marioni & 0.70 & & & 0.03 & & Nassarius sp. & & & 0.28 & & \\
\hline Chaetozone setosa & 3.80 & & & & & Mangelia coarctata & & & 1.06 & 0.25 & 0.02 \\
\hline Cirriformia tentaculata & & 0.10 & & & & Nucella lapillus & & 0.10 & & & \\
\hline Spiochaetopterus costarum & 0.94 & & & 0.01 & & Odostomia scalaris & & 0.17 & & & \\
\hline Paraonis fulgens & 2.74 & & 0.13 & 0.18 & & Gibbula cineraria & & 0.24 & & & \\
\hline Capitella capitata & 0.57 & 0.27 & & & & Echinoderms & & & & & \\
\hline Heteromastus filiformis & 47.34 & & & 0.01 & & Amphiura chiajei & 3.58 & & 0.11 & 0.38 & 0.01 \\
\hline Notomastus latericeus & 3.60 & & 12.79 & 8.43 & & Amphiura filiformis & 2.23 & & 0.11 & 0.55 & \\
\hline Arenicola ecaudata & & 0.29 & & & & Leptosynapta bergensis & 0.65 & & & & \\
\hline Maldane glebifex & 0.45 & & & 0.03 & & Cucumaria normani & & 1.54 & & & \\
\hline Euclymene oerstedii & 0.89 & & & & & Amphipholis squamata & & 0.78 & & & \\
\hline $\begin{array}{l}\text { Sternaspis scutata } \\
\text { Pectinariidae, undet. }\end{array}$ & 0.96 & & 0.19 & $\begin{array}{l}0.08 \\
0.03\end{array}$ & 0.03 & Crustaceans & & & & & \\
\hline Melinna palmata & 1.18 & & & 0.38 & & Mysidaceae, undet. & & & 0.76 & 0.20 & 35.57 \\
\hline Ampharete acutifrons & 1.95 & & 0.87 & 1.41 & & Pisidia longicornis & 2.17 & 17.80 & 67.08 & 54.56 & 36.09 \\
\hline Polycirrussp. & 2.51 & & & & & Inachus dorsettensis & & & & 0.01 & \\
\hline Lanice conchylega & & & 0.19 & 0.04 & & Eualus occultus & & 0.10 & & & \\
\hline Pomatoceros triqueter & & 0.32 & & & & Hyppolite varians & & 0.35 & & & \\
\hline Leanira yhleni & 0.65 & & & & & Paguridae, undet. & 1.91 & & & 0.79 & \\
\hline Harmothoesp. & 2.20 & 0.76 & & & & Caprella aequilibrâ & & 4.48 & 5.87 & 1.72 & 0.21 \\
\hline Eulalia fucescens & 0.35 & & & 0.01 & 0.04 & Phtisica marina & 0.57 & 25.41 & 3.90 & 0.92 & 1.60 \\
\hline Gyptis capensis & 1.62 & & & & & Pseudoprotella phasma & 0.07 & 1.45 & 2.14 & 2.17 & 6.20 \\
\hline Ophiodromus flexuosus & 0.95 & & & & & Ampelisca sp. & 0.96 & & 0.19 & 1.31 & 0.49 \\
\hline Nereidae, undet. & & & & 0.04 & & Apherusa jurinei & & 0.12 & 0.43 & 16.34 & 15.68 \\
\hline Nephtys hystricis & 0.35 & & 0.06 & & 0.01 & Aora typica & & 1.55 & 2.20 & 6.86 & 0.07 \\
\hline Glycerasp. & & & 0.03 & & 0.02 & Jassa falcata & & 1.71 & 1.27 & 0.54 & 3.05 \\
\hline Lumbrineris sp. & 2.20 & & & 0.03 & & Stenothoesp. & & 0.08 & 0.19 & 1.08 & 0.39 \\
\hline Molluscs & & & & & & Eurysteus maculatus & & 14.99 & & & \\
\hline Mytilus edulis & & 17.10 & & 1.15 & 0.51 & Corophium sextoni & & 5.87 & & & \\
\hline Abra alba & 2.36 & & & 0.04 & & Lembos websteri & & 3.72 & & & \\
\hline Nucula sulcata & 0.16 & & & 0.01 & & Panoploea minuta & & 0.29 & & & \\
\hline Mysella bidentata & 0.64 & & & 0.01 & & Cirolanasp. & 0.32 & & & & \\
\hline Chlamys sp. & & & & 0.04 & & Tanaidacea, undet. & & & & 0.03 & \\
\hline Venerupis pullastra & & 0.12 & & & & Balanus perforatus & & 0.26 & & & \\
\hline Venus sp. & 0.25 & & 0.15 & 0.14 & & Nebalia bipes & & & & 0.06 & \\
\hline Corbula gibba & 0.07 & & & 0.01 & & Total & 1568 & 16361 & 5277 & 7036 & 10341 \\
\hline Myrtea spinifera & 0.30 & & & & & & & & & & \\
\hline
\end{tabular}

epifauna and fish stomachs (Fig. 5) show that the 3 fish species had a much smaller proportion of mussels in their stomachs than present in the raft epifauna, resulting in a negative value of the electivity index. This fact might be expected, because mussels are not a suitable prey for these small fish. Another point is the positive electivity of the 3 fish species of the small decapod Pisidia longicornis, whose proportion in the stomachs reached $67 \%$ of the total diet. However, the electivity was always negative in respect to the caprellid Phtisica marina, which is also very dominant in the raft epifauna. The proportion of the rest of species, both in stomachs and in raft epifauna, is so small that it would be difficult to draw significant conclusions from the electivity values.
The values of the Morisita index of similarity used as a measure of prey overlap among fishes were very high (> $65 \%$ ), indicating a great similarity among the 3 fish diets (Fig. 6). Callionymus lyra and Lesueurigobius friesii had the highest similarity (93\%), due to the high proportion of Pisidia longicornis in their diets. Infaunal polychaetes (e.g. Notomastus latericeus) are also important for both species. Trisopterus luscus had also a high similarity with Callionymus lyra (72\%) and Lesueurigobius friesii ( $65 \%$ ), again because of shared Pisidia longicornis prey. However, the values were not as high as in the case of C. Iyra $-L$. friesii, because $T$. Iuscus preys on a wider range of crustaceans (mysidacea and amphipods) and does not feed upon infaunal polychaetes. 


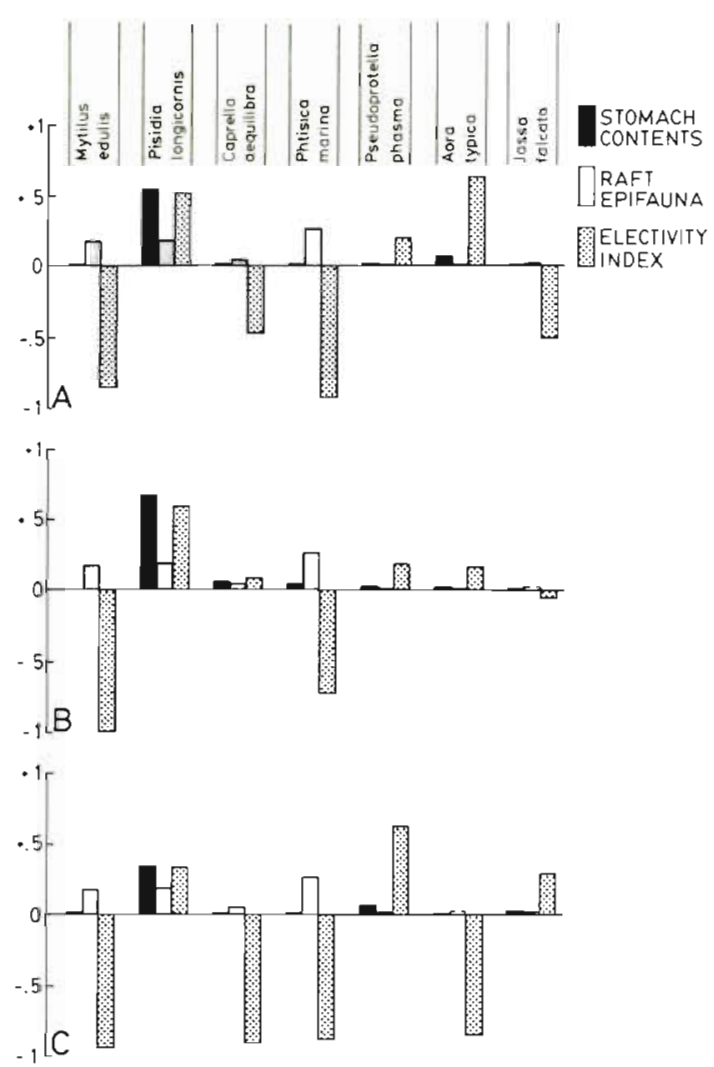

Fig. 5. Proportion of main food items in fish diets and in raft epifauna. Electivity index according to Ivlev. A: Callionymus lyra; B: Lesueurigobius friesii; C: Trisopterus luscus

\section{DISCUSSION}

Intensive raft culture of the edible mussel Mytilus edulis in the Ría de Arosa affects the local food-chain patterns. Total biomass of raft epifauna in the Ría de Arosa is extremely high compared with epifaunal cornmunities in similar areas. In contrast, the infaunal macrobenthos of the Ría de Arosa is very depauperate, and is dominated by pioneering species typical of eutrophied environments (López-Jamar, 1982). The reason of scarcity of infauna is the great amount of organic detritus settling from the rafts that cannot be utilized entirely by infaunal organisms, resulting in anoxic sediments and in very low infaunal densities (Tenore et al., 1982).

The 3 fish species studied preyed primarily on raft epifauna. The proportion of infaunal prey consumed was very small. These results confirm the hypothesis that raft epifauna serves as the main food resource for the demersal fish. For the 3 fish species, only a restricted number of epifaunal prey species is utilized. Pisidia longicornis is the major component of the diet in all the stomachs examined, giving always positive
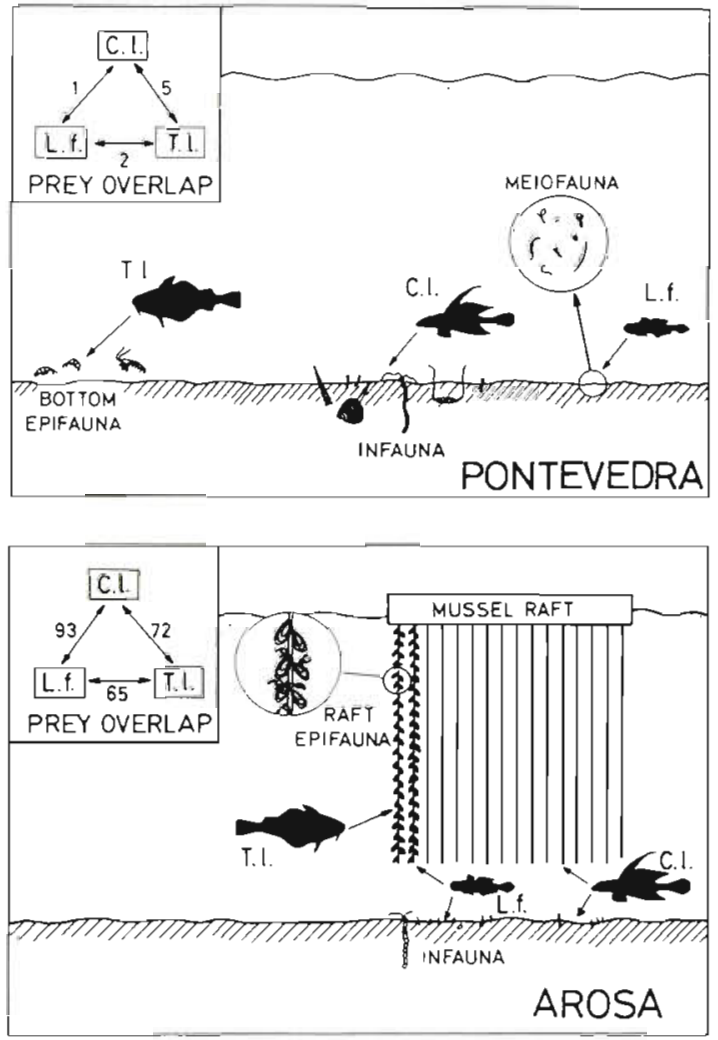

Fig. 6. Feeding habits of the 3 fishes studied in a ria with little influence from the rafts (Ría de Pontevedra), and in the Ría de Arosa, much affected by the mussel rafts. Left corners: prey overlap of fish diets (abbreviations as in Fig. 2)

values of the electivity index. This means that it is selected preferably to other available prey.

The fact that the diet of fish is composed primarily of raft epifauna causes a high level of prey overlap. Although much emphasis has been placed in the past on a cause-and-effect relation between prey overlap and competition, such a potential relation depends on the degree of food-resource availability. Thus, the high prey overlap observed in the fishes studied of the Ría de Arosa does not necessarily mean actual competition for food, because the great abundance of available prey in the raft epifauna allows the fishes to feed on the same resource with relatively little exploitation competition.

In contrast, in other estuarine areas and in rias much less affected by mussel culture, such as the Ría de Pontevedra and Ría de Muros, demersal fishes feed mainly on infauna, and epifauna is only utilized in restricted areas. In the nearby Ría de Pontevedra, the prey overlap among these 3 fish species was very low ( 1 to $5 \%$ ) (Iglesias and López-Jamar, unpubl.) in contrast with much higher values in the Ría de Arosa (65 to $93 \%$ ) (Fig. 6). This indicates a wider range of food 
selection in the Ría de Pontevedra. In this ría, Callionymus lyxa feeds mainly on infaunal polychaetes, Lesueurigobius friesii on meiofauna (nematodes, harpacticoid copepods, etc.), and Trisopterus luscus on crustaceans, although because of the much smaller density of mussel rafts, these are bottom epifaunal crustaceans (amphipods, mysids). Therefore, the main effect of the mussel-raft culture in the benthic food web of Ría de Arosa is the great development of a raft epifaunal community and an impoverishment of infaunal benthos, resulting in a change of the main source of food for demersal fish.

In conclusion, intensive aquaculture in estuarine areas might change the patterns of benthic food webs; therefore, comprehensive studies of different trophic levels should be carried out in order to have a better understanding of estuarine ecosystems managed by man.

Acknowledgements. This research was supported by funds of the United States - Spanish Cooperative Program No. 0020, of Skidaway Institute of Oceanography (Georgia, USA) and the Instituto Español de Oceanografía (Spain). We wish to thank Mr. J. Mejuto for his help in fish-stomach analysis.

\section{LITERATURE CITED}

Arntz, W. E. (1978). The 'upper part' of the benthic food web: the role of macrobenthos in the Western Baltic. Rapp. P.-v. Reún. Cons. int. Explor. Mer 173: 85-100

Chesney, E. J. Jr., Iglesias, J. (1979). Seasonal distribution, abundance and diversity of demersal fishes in the inner Ría de Arosa, North West Spain. Estuar. coast. mar. Sci. 8: $227-239$

Gibson, R. N. (1969). The biology and behaviour of the litoral fish. Oceanogr. mar. Biol. A. Rev. 7: 367-410

González-Gurriarán, E. (1981). La nécora Macropipus puber (Linnaeus, 1767) (Decapoda, Portunidae), en los polígonos de bateas de la Ría de Arosa: contribución al estudio de su biología. Resumen Tesis Doctoral Univ. Santiago

Haedrich, R. L., Haedrich, S. O. (1974). A seasonal survey of the fishes in the Mystic River, a polluted river in downtown Boston, Massachusetts. Estuar coast. mar Sci. 2: $59-73$

Horn, H. S. (1966). Measures of 'overlap' in comparative ecological studies. Am. Nat. 100 (914): 419-424

Iglesias, J. (1981). Spatial and temporal changes in the demersal fish community of the Ría de Arosa (NW Spain). Mar. Biol. 65: 199-208

Iglesias, J. (1982). Ecología de la comunidad de peces demersales de la Ría de Arosa, con especial referencia a la familia Gobiidae. Resumen Tesis Doctoral Univ. Santiago

Ivlev, V S. (1961). Experimental ecology of the feeding of fish. Yales University Press, New Haven

Jones, R. (1978). Some observations on competition between some gadoid fish species. Rapp. P.-v. Reún. Cons. int. Explor Mer 172: 292-300

Korringa, P. (1967). Estuarine fisheries in Europe as affected by man's multiple activities. In: Lauff, G. H. (ed.) Estuaries. AAAS, Washington D. C., Publ. No. 83: 658-663

López-Jamar, E. (1982). Distribución espacial de las communidades bentónicas infaunales de la Ría de Arosa. Boln Inst. esp. Oceanogr. 7 (2): 255-268

Morisita, M. (1959). Measurement of interspecific association and similarity between communities. Mem. Fac. Sci. Kyushu Univ. (Ser. E) 3: 65-80

Román, G., Pérez, A. (1982). Estudio del mejillón y de su epifauna en los cultivos flotantes de la Ría de Arosa. IV. Evolución de la comunidad. Boln Inst. esp. Oceanogr. 7 (2): $279-296$

Tenore, K. R., Boyer, L. F., Cal, R. M., Corral, J., GarcíaFernández, C., González, N., González-Gurriarán, E., Hanson, R. B., Iglesias, J., Krom, M., López-Jamar, E., McClain, J., Pamatmat, M. M., Pérez, A., Rhoads, D. C., de Santiago, G., Tietjen, J., Westrich, J., Windom, H. (1982). Coastal upwelling in the Rías Bajas, N. W. Spain: contrasting the benthic regimes of the Rías de Arosa and de Muros. J. mar. Res. 40: 701-772

Tenore, K. R., González, N. (1975). Food chain patterns in the Ría de Arosa, Spain: an area of intense mussel aquaculture. In: Persoone, G., Jaspers, E. (ed.) 10th European Marine Biology Symposium, Vol. 2. Universa Press, Wetteren, p. 601-619 